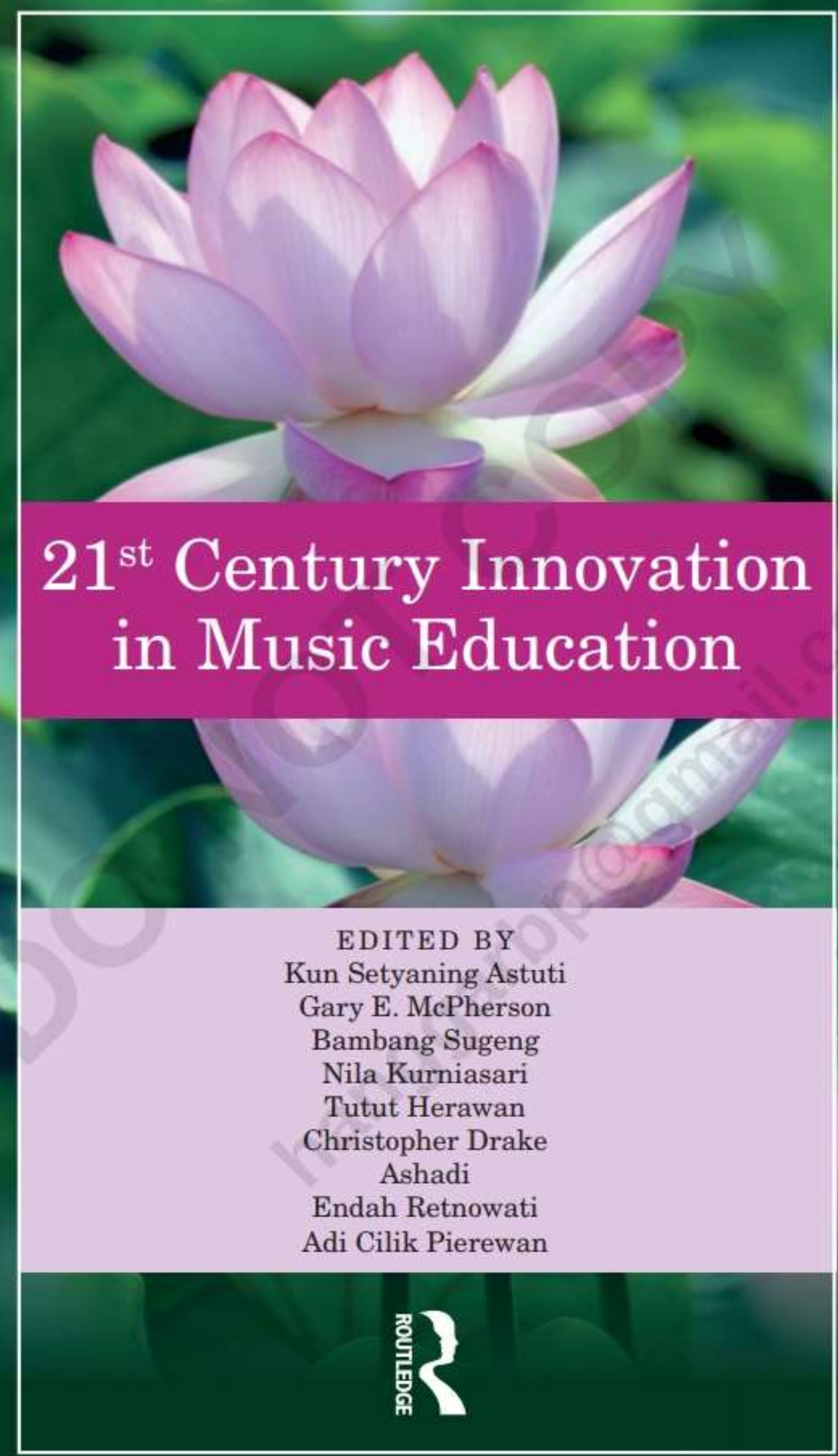


2020 Taylor \& Francis Group. London. UK

Typeset by Integra Software Services Prt. Ltd. Pondicherry, India

All rights reserved. No part of this publication or the information contained herein may be reproduced, stored in a retrieval system. or transmitted in any form or by any means. electronic, mechanical, by photocopying, recording or otherwise, without written prior
permission from the publisher.

Although all care is taken to ensure integrity and the quality of this publication and the information herein, no responsibility is assumed by the publishers nor the author for any damage to the property or persons as a result of operation or use of this publication and/or the information contained herein.

Published by: CRC Press/Balkema

Schipholweg 107C, 2316XC Leiden, The Netherlands

e-mail: Pub.NL a taylorandfrancis.com

www.crepress.con - www.taylorandfrancis.com

ISBN: $978-0-367-11122-9(\mathrm{Hbk})$

ISBN: 978-0-429-02493-1 (eBook)

DOI: https//doi.org/10.1201/9780429024931 


\section{1st Century Innovation in Music Education}

\section{Editors}

Kun Setyaning Astuti

Universitas Negeri Yogyakarta. Indonesia

Gary E. McPherson

The University of Melbourne, Australia

Bambang Sugeng

Universitas Negeri Yogyakarta, Indonesia

Nila Kurniasari

Universitas Negeri Yogyakarta, Indonesia

Tutut Herawan

Universitas Teknologi Yogyukarta, Indonesia

Christopher Drake

Living Vahes Education, $U K$

Ashadi

Universitas Negeri Yogyakarta, Indonesia

Endah Retnowati

Universitas Negeri Yogyaharta, Indonesia

Adi Cilik Pierewan

Universitas Negeri Yoglakurta, Indonesia 


\section{Table of contents}

Prefice

Organizing Committee

Scientific Committee

Acknowledgement

\section{Higgins}

The position of humans in the Karawitan lyrics of Ki Narto Sabdo: An ecocritical perspective

S.A. Sayuti

Ethnomusicology of The Dawn: Understanding the intergenerational impact of their song

'Salamat'

E.T. Lianta

The existence of Hailee Steinfeld ('Haiz') fans in Indonesia: An academic perspective

J. Francoise

The pervasiveness of $K$-pop in 21 st century Indonesia

P. L Langit, K.S. Astut, A. Yuliwhi \& R.M. Nasution

Teaching music for communicating and sharing information in the Malian traditional society T. Kasse \& K.S. Astui

Music bibliography of South Kalimantan (1978-2017)

S. Hadt

Ditherences in developing musical competencies in Indonesia. The Netherlands, and France K.S. Astut, A. Armin, H. Sri Mudhah, E.Th.M. Bifsterved, S. Frede \& W. Veugelers

The role of music education in promoting moral behaviour among children M.U. Okeke

Music learners and the profile of music teachers in the digital world: The Nigerian scenario P.C.Ovoughuth

The influence of deep learning model on musicality and character through Dolanam songs K.S. Astm, M.G. Widyasmi \& HT. Shlach

Developing instructional multimedia for learning traditional music by encyclopedia form N.A. Anandhita \& S shartiwi

Multimedia Tulempong Pucik learning: Virtual instrument based on Android

B.F.F. Zerkid K.S. Astur 
The effects of applying games in music class on character and learning achievements

Learning through an interactive multimedia CD to strengthen musicality and character values

Gamolan multimedia: An innovative media for traditional musical instrument learning
I.K.S.S. Pura \& A.N. Machaucia

MIDI as a medium for improving student's vocal abilities in the choir learning

Experimenting Sing, Sign and Play method in an elementary school to improve musical learning

R.L. Ulfa d A.N. Machfauzia

The implementation of the Suzuki method in Tingkilan music extracurricular learning

An effort to increase learning outcomes in musical scale teaching using the PILKABE: strategy

Boman

Keroncong multimedia: An alternative music learning media

D. A.P. Anggara \& A.N. Machfauzia

Bringing $21^{\text {st }}$ century music skills to the curriculum through interdisciplinary study

The impact of the UK curriculum on the musicality of Indonesian students

Privadi \& KS. Asmi Increasing sight-reading ability through implementation of the Super Sight-Reading Secrets
programme

Z.A.W. Putra \& K.S. Astuti

The effect of collaborative learning on the Rmding Gwmbent music skills and appreciation

Vocal learning efforts to increase music teachers abilities in Panh Dewi kindergarten

P.P Rusdewanti, D. Kristianingsih \& D. Jogianingrun

Comparison of cognitive and improvisational learning models on music students" learning

The effectiveness of vocal learning using the drill learning method

N.R.D. Arini \& H.S. Mudihah

Early inculcation of character values through children's songs

H. Y. Wicaksono. Agustianto \& Y.J. Firia

Effect of a backing track on improvement of students' electric guitar playing skills

A. Suprayogid K.S. Astuti

How music education can contribute to moral development and citizenship?

W. Vengelers d J. Terlingen

Musical ability effect on interpersonal intelligence. empathy and self-confidence

A revitalization of Lubuklinggat folk songs to engratt the patriotism 
Gandang Tambua \& Tasa: Elements of music and relevance to character education M. Aflhal \& A. N. Machfarzia

Auditive stimulation of dance acompaniment in the Soka Kinant art studio as a method of increasing kinesthetic intelligence

G.K.W. Anggraheni. K.S. Astuti, A. Husna \& W.O. Wikn

Cultivating the spirit of nationalism through the song Manuk Dadali'

S.R. Malmudah \& Sumariadi

The value of local wisdom in children's song for character education

M. Y. Putraip. K.S. Astuti \& Y. Fitriano

Gamelan music therapy to train the imner sensation to get the feeling of the dance

D.A. Fajar \& R. Wharsih

Educational values in the Erpangir Ku Lau ritual

A.P.H. Purba \& K.S. Asmi

Moral teaching in children's religious songs

G. Dwitantoro \& H. Panadhi

Developing character values through Javanese gamelan

A. Pronata \& S. Rudiati

Tolerance education through a choral lesson in schools

O. Pratama \& K.S. Astuti

The educational values in the art of Randai Sutan Budiman in Kambang Lengayang

J. Yulandri \& A.N. Madfatioia

Meanings in the Orang Rimba ritual honey-gathering song in Jambi, Indonesia

D.N. Anggraini \& S Pradoko

An analysis of Rokan hik hymn song as a learning materal for music subject in school

A. Husna, A.M.S. Pradoko W. O Wiko \& G.K.W. Anggraheni

The relationship between folk song and people 's moral education

A. Yunanto \& H. Pamadhi

Kuadai dance music and symbolic meaning as a medium for early childhood learning

Hartono o R. lanjur A.H. Saputri \& B. Sunty

Educational values through Senjang songs in Sekayu. Musi Banyuasin Regency

A.R. Purnamatari \& S. Pradoko

Efforts to enhance research methodology achievements through classroom interactions H.S. Mulikh

The effects of peer group behavior on attention to the gamelan among teenagers

Y. Delvinita \& Djohan

Children's learning of Dolanan songs in the digital era

E. Norhatati \& K.S. Astu

The revivals of Haydn's oratorio The Creation

T. Bramanto

The perspective of Western music in wayang kult gamelan Y.E. Susilo

Opening melody for pater sound space on shadow puppet theatre

H.B. Prasetya, I.K.N Pura \& T. W. Widodo 


\section{Preface}

There are laws of a certain nature in the natural sciences and likewise in music there are structures and procedures, or even rules, that should be followed to produce beautiful music. Thus. music is not only something that has subjective appeal according to the unique taste of each individual's sense of art and beauty but may also be studied in an objective fashion as a form of science. Music is not only something that can be felt but also something that can be
counted.

The developmental journey of science that puts music only to the specialization of social sciences and humanities is inhibiting the development of theories that can explain and construct music as part of the discipline, capable of contributing to advancements in other fields such as: natural sciences, psychology, medicine, etc. For most of the music communities, the view that music is only a part of the entertainment media can be disregarded by developing both basic and applied theories that are interconnected with science, including natural science.

Considering the importance of implementation and development of innovation in music education, both basic and applied theories, as well as its connection with other disciplines, we organized an international conference with the theme 21 st Century Imovations in Music and Research Edacation. The $1^{\text {st }}$ International Conference on Music Education Community (INTERCOME) 2018 was held on 25-26 October 2018 in the Music Department of the Lan-

guages and Arts Faculty, Yogyakarta State University, Indonesia. This conference is held
once every three years (triennially).

INTERCOME intended to capture the latest musical developments and brought together tors, researchers, observers and research results.

This volume of proceedings presents 71 selected articles from 127 articles presented at the 2018 INTERCOME seminar attended by participants from 10 countries. The authors who made it through the selection are from six countries, namely Britain, Indonesia, Mali. Nigeria. the Netherlands, and the Philippines. Many papers were written by senior authors such as
Prof Lee Higgins. Pho Prof. Lee Higgins. Ph.D.. former President of ISME (International Society for Music Education), Prof. Dr. Suminto A. Sayuti. former Dean of Faculty Languages and Arts of Universitas Negeri Yogyakarta, Prof. Endang Nurhayati. Dean of Languages and Arts of Universitas Negeri Yogyakarta, Prof. Triyono Bramantyo. former Dean of the Faculty of Performing Arts of the Institut Seni Indonesia Yogyakarta Indonesia and Prof. Wiel Veugelers, a moral education expert from the University of Humanistic Studies, Utrecht, the Netherlands who writes about the role of music as a character-foming tool. This proceeding covers seven
themes. They are as follow:

1. Picture of $21^{\text {st }}$ century music education in the world

2. The innovation of curriculum, teaching and learning media and technological and enviromental evaluation in accordance with the development in the $21^{\text {st }}$ century.

3. The development of music as an educational media in the post globalization era 4. The harmonious existence of eastern, western. traditional, and modern music for all types
of music in the digital revolution era

5. The development of critical thinking ability to respond to various phenomena of the latest music 
6. Collecting, developing. and constructing the basic theory of the relationship and the effect of music on psychology, physics, social and other disciplines or vise versa and its utilization
in modern human life

7. Music research development in the $21^{\text {st }}$ century

We hope that it will encourage theoretical and practical views, concepts. research results and principles to further support the development of music educations and other related fields.

Dr. Kun Setyaning Astuti. M.Pd. 


\section{Organizing Committee}

\section{Patron}

Prof. Dr. Sutrisna Wibawa, M.Pd. (Rector of Universitas Negeri Yogyakarta) UNY

\section{Advisory Committee}

Prof. Dr. Margana, M.Hum (Vice Rector of Academic Affairs, Universitas Negeri Yogyakarta)

Prof. Dr. Edi Purwanto, M.Pd. (Vice Rector of Finance, Universitas Negeri Yogyakarta)

Prof. Dr. Sumaryanto, M. Kes (Vice Rector of Student Affair. Universitas Negeri Yogyakarta)

Dr. Rer.Nat. Senam, M.Si. (Vice rector of internationale affairs in partnership. UNY)

Prof. Endang Nurhayati, M.Hum (Dean of Languages and Arts Faculty)

Dr. Maman Suryarman, M.Pd. (Vice Dean of Academic Affairs-Languages and Arts Faculty of Universitas Negeri Yogyakarta)

Rohali. M.Hum.(Vice Dean of Financial affairs-Languages and Arts Faculty of UNY)

Head of Organizing Committee
Dr. Kun Setyaning Astuti, M.Pd. (Vice Dean of Students Affatirs

\section{Local Organizing Conmittee:}

Dr. Ayu Niza Machfauzia, M.Pd. (Head of Music Education Departement) Sritanto, M.Pd. (Secretary of Music Education Departement)

\section{Secretary:}

Nila Kurniasari, S.Pd. ,M.Pd.

Fransisca Xaveria Diah

Kristianingsih, S.Pd., M.A.

Treasure:

Panca Putri Rusdewanti.

S.Pd...M.Pd.

Dra. MG. WidyastutI. M.Sn.

Special Season Chair:

Herwin Yogo W, M.Pd.

Heni Kusumawati, M.Pd.

\section{Sponsorship:}

Drijastuti Jogjaningrum. M.A.

Fuadi,M.A.

Dr. Cipto Budi Handoyo, M.Pd.

Agustianto, M.Pd.

\section{Technical support:}

Pujiwiyana, M.Pd.

Agus Untung Yulianto, M.Pd.

Mudakir, S.Ip.

Drs. Sugeng Tri Wuryanto.
Program Committee Chair:

Yunike Juniarti Fitria, M.A.

\section{Proceeding chair:}

Dr. A.M. Susilo Pradoko, M.Si.

Dr. Hanna Sri Mudjilah, M.Pd.

Suwarta Zebua, M.Pd.

HT. Silaen. M.Hum.

Admin/secretariat:

Virga Renitasari, S.Pd.

Altri Rohmat, A.Md.

Suryati, S.Pd.

Sariyanto, S.Pd.

Sinto Wibowo. S.Pd.

Rini Lestari

Design:

Sugeng Setia Nugroho, A.Md.

Dedy Sartono, S.Pd. 


\section{Scientific Committee}

Chair of Editor: Dr. Kun Setyaning Astuti, M.Pd.

Editors:

2. Prof. Gary E. McPherson, Ph.D.

3. Bambang Sugeng, Ph.D.

4. Nila Kurniasari, M.Pd.

5. Dr. Tutut Herawan

6. Christopher Drake, M.A.

7. Ashadi, S.Pd..M.Hum.,Ed.D.

8. Endah Retnowati, Ph.D.

9. Adi Cilik Pierewan, Ph.D.

Reviewer

Prof. Dr. Triyono Bramantyo (ISI Yogyakarta-Indonesia)

Prof. Dr. Meiyao Wu (Departmen of Education Director of Academic Affairs Section

(Heping Campus) National Kashiung Normal University. Taiwan.

Dr. Susilo Pradoko,M.Si.(Universitas Negeri Yogyakarta-Indonesia)

Dr. Ayu Niza Machfauzia, M.Pd.(Universitas Negeri Yogyakarta-Indonesia)

Dr. Hanna Sri Mudjilah, M.Pd. (Universitas Negeri Yogyakarta-Indonesia)

Dr. Cherry Russell (University of Sydney)

Dr. Wayland N Quintero (University of Hawai'i)

Suhaini M. Saleh (Universitas Negeri Yogyakarta)

Edijana Ursula (City University of Hongkong)

Mei Yee Wong (Education University of Hongkong)

Maosen Li, Renmin University. Beijing, China

Qian Zhang. Guangdong University of Foreign Studies, China

Mei-Yee Wong, The Education University of Hong Kong. Hong Kong 


\section{Acknowledgement}

This page is dedicated to the people who have been a tremendous support in the making of this proceeding. This work would not have been possible without the patronage of the Rector of Yogyakarta State University, Prof. Dr. Sutrisna Wibawa, M.Pd. and his staff, who have been supportive all the way.

I would also like to express our deepest gratitude to the board of editors Prof. Gary E. McPherson, Bambang Sugeng, Ed.D., Tutut Herawan, Ph.D., Endah Retnowati, Ph.D, Christopher Drake, M.A.. Ashadi, Ed.D. Nila Kurniasari, M.Pd., Adi Cilik Piereawan and to all reviewers for their suggestions, encouragement, and for ensuring the quality of the papers published.

Beside that, I would also like to express our deepest gratitude to the following people for their contribution for this conference:

Dr. Rernat. Senam (Universitas Negeri Yogyakarta)

Prof. Lee Higgins (York St. John University)

Ass. Prof. Julie Ballantyne (University of Queensland. Australia)

Servaas Schreuders (Hogeschool voor De Kunsten Utrecht. The Netherlands)

Prof. Dr. Suminto A. Sayuti (Universitas Negeri Yogyakarta)

Dr. Clare Suet Ching Chan (Universiti Pendidikan Sultan Idris)

Janjaap Blom (Senior Publisher, CRC Press/Balkema, Taylor \& Francis - the Netherlands)

Dr. Cherry Russell (University of Sydney, Australia)

Wayland N Quintero (University of Hawaii)

Supriyanto Wardoyo. SE (Universitas Sanata Dharma)

Prof. Dr. Suwarsih Madya, Ph.D (Universitas Negeri Yogyakarta)

Suhaini M. Saleh (Universitas Negeri Yogyakarta)

Soni Nopembri, Ph.D (Universitas Negeri Yogyakarta)

Mungad (Universitas Negeri Yogyakarta)

Meiyao Wu (National Taiwan Normal University)

Eddy K.M Chong (National Institute of Education. Singapore)

Prof. Wiel Veugelers (University of Humanistic Studies, Utrecht. The Netherlands)

Mei Yee Wong (Education University of Hongkong)

Dr. Marlene Belly (Poitiers University, France)

Edijana Ursula (City University of Hongkong)

Setyo Purwaningsing, M.Sc (University of Bristol)

Rasman (University of Birmingham)

Furthermore, I would also like to acknowledge with much appreciation, the crucial role of the ISME (International Society of Music Education) and APNME (Asia Pacific Network of Moral Education) for their valuable contribution. A very special gratitude goes to the INTERCOME committee and students committee for their dedication and efforts in preparing and hosting the conference.

I am also grateful for the support of English Department alumni of Universitas Negeri Yogyakarta who have been a great help in proofreading the manuscripts. Last but not least, I would 
like to give my thanks to the publisher for their cooperation and for allowing us the opportunity to publish the conference papers. Appreciation also goes to José van der Veer and Lukas Goosen with their team who worked hard in correcting the draft and thereby making it more
perfect.

Sincerely Yours

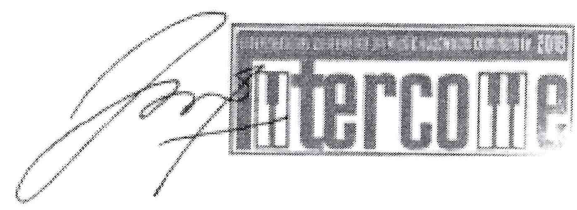

INTERCOME Organizing Committee Chair

Dr. Kun Setyaning Astuti, M.Pd. 


\title{
Opening melody for patet sound space on shadow puppet theatre
}

\author{
H.B. Prasetya, I.K.N Putra \& T.W. Widodo \\ Indonesia Institute of the Arts, Yogyakara. Daacrah Istmewa Yogykarta, Indonesia
}

\begin{abstract}
This study aims to understand the various types of melodies that play a role as opening patets (gamelan mode) in wayang (shadow-puppet theatre). The data for this study was obtained by observing the Kakrasana Wanengpinta shadow-puppet performance. Observations was focused on the parts that have changes in patet. Based on the research it can be concluded that there are two types of melodies used in the transition of patet changes, namely thinthingan and grambyangan, additionally, the vocals of the puppet master (dalang) who mimics thinhingan. Thinthingan and grambyangan are carried out by the gender, one of methallophone gamelan instruments. Thinthingan melodies are needed for light transitions, while grambyangan melodies are used for heavy transitions.
\end{abstract}

\section{INTRODUCTION}

Gamelan music plays an important role in wayang or shadow-puppet theatre. The resulting musical sense plays a role in strengthening the atmosphere needed in the scene and gives a certain sense of character to the characters played in the shadow-puppet theatre (Lyslofr, 1993). In other words, gamelan music functions to support the atmosphere in the scenes so that it supports the essence of the play that is performed. Therefore, without gamelan music, shadow-puppet theatre cannot take place.

The importance of gamelan music in Yogyakarta-style shadow-puppet theatre is reflected in the jejêran (main scene) in the performance. Traditionally, shadow-puppet performances are divided into three segments determined by the patet, namely patet nem, patet sanga, and patet manyura (Weiss, 2006). During the overnight performance of wayang, patet nem takes place between 9:00 p.m. to 12:30 a.m, patet sanga between 12:30 p.m. to 03:00 a.m. and patet manyura between 3:00 a.m. to 04:00 a.m. In these large segments most of the musical events are associated with patet. In shows with shorter duration, the patet division adjusts the duration of the show. Generally, patet nem and patet sanga are longer than patet manyura.

Each patet consists of jejeran and each jejerran often consists of scenes (Prasetya, 2013). Patet nem comprises jejer I or jejèr kawitan, jejêr II or jejêr sabrangan and jejêt III or jejêr bondhèt. Patet sanga comprises jejêr IV or jêjer pandhita and jejer V or jêjêr whuk-uluk. Pater manyura comprises jejerr VI or jejer stanirat and jejêr VII or jêter rina-rina (see Table 1). The terms bondhet, whk-uhk, Swmirat and rina-rina refer to gending or the gamelan piece name that is usually used in that scene. Although other gending is sometimes used in jejeran, the jejer stays the same.

The distribution of patets in shadow-puppet performance is related to the type of gending or gamelan piece used. In the patet nêm section, the compositions are ném-bound compositions. In the patet sanga section, the compositions used are sanga-themed compositions. Likewise, in patet manyura, the gending used is the manyura-style compositions. However, in some parts, the patet changes. For example, the budhalan scene is in the patet nem segment, but often uses a number of sanga-themed compositions, and likewise in the goro-goro scene. This scene is actually in the patet sanga segment, but often uses manyura-style compositions (see Table 3 ). 
Table 1. The relation of Pater with scenes and Jejeran in the play of Kakasrana Womengpinta

\begin{tabular}{|c|c|c|c|}
\hline Patet & Jejer Name & Scene/Act Natme & Character \\
\hline \multirow[t]{9}{*}{$\mathrm{Nem}$} & \multirow[t]{5}{*}{ 1. Kawitan } & Mandura country & $\begin{array}{l}\text { Prabu Basudewa, Haryaprabu, Patih Saragupito, } \\
\text { Tumenggung. Narayana. }\end{array}$ \\
\hline & & Kundur kedaton & Prabu Basudewa \\
\hline & & Paseban Jawi & Haryaprabu, Narayana, Patih Saragupita, soldiers. \\
\hline & & Budhalan & Haryaprato, Patih Saragupita, soldiers. \\
\hline & & Ampyak war & $\begin{array}{l}\text { Soldier's journey of Mandura country } \\
\text { Patih Nauarange }\end{array}$ \\
\hline & 11. sabrangan & $\begin{array}{l}\text { Girigathok country } \\
\text { Simpangan war }\end{array}$ & $\begin{array}{l}\text { Patih Nagarangsang. Bedongbau. Bramangkara } \\
\text { The battle of Mandura soldiers against Girigathok } \\
\text { soldiers }\end{array}$ \\
\hline & \multirow[t]{3}{*}{ III. bondher } & $\begin{array}{l}\text { Jongringsaloka } \\
\text { heaven }\end{array}$ & Batara Guru, Narada, Brama, Endra \\
\hline & & $\begin{array}{l}\text { The } \\
\text { Repatkepanasan }\end{array}$ & Narada. Brama, Endra, Sambu. Yamadipati \\
\hline & & Gagal wat & $\begin{array}{l}\text { The battle of Patih Nagakilat. Gedongbau, and Bra- } \\
\text { mangkara against Brama and Endra }\end{array}$ \\
\hline \multirow[t]{4}{*}{ Sanga } & \multirow[t]{3}{*}{ 1V. pandhita } & Gora-goro & Semar, Gareng, Petruk. Bagong \\
\hline & & Ringin Gedabya & $\begin{array}{l}\text { Begawan Wanengpinta, Margana, Semar, Gareng, } \\
\text { Petruk, Bagong }\end{array}$ \\
\hline & & $\begin{array}{l}\text { Hermitage } \\
\text { Begal war }\end{array}$ & $\begin{array}{l}\text { Petruk, Bagong } \\
\text { The battle of Margana against Cakil and soldiers of } \\
\text { Girigathok }\end{array}$ \\
\hline & V. whik-ruhu & $\begin{array}{l}\text { Surateleng heaven } \\
\text { Tanggung war }\end{array}$ & Nagaraja, Dewi Pertiwi, Setija, Narayana \\
\hline \multirow[t]{4}{*}{ Manyura } & \multirow[t]{2}{*}{ VI. sumirat } & Girigathok country & Prabu Nagakilat catching up Nagarangsang \\
\hline & & Tandang war & $\begin{array}{l}\text { The lost of Margana in the war against Nagakilat. The } \\
\text { war between Wanengpinta against Nagakilat and } \\
\text { Nagarangsing. The lost of Nagakilat, then he turns } \\
\text { into at weapon called Nanggala while Nagarangsang } \\
\text { turns into Alugara. }\end{array}$ \\
\hline & \multirow[t]{2}{*}{ VII. rina-rina } & Mandura country & $\begin{array}{l}\text { Prabu Basudewa, Kakrasana, Narayana, Permadi. } \\
\text { Haryaprabu, Semar, Gareng. Petruk, and Bagong }\end{array}$ \\
\hline & & Brubuh war & $\begin{array}{l}\text { The batle of Werkudara against soldiers of } \\
\text { Girigathok. }\end{array}$ \\
\hline
\end{tabular}

Source: Hanggar and Nuryanto (2018).

Before the 1970 s, shadow-puppet shows were only accompanied by the gamelan in slendro scale. Along with the development of gamelan music and the shifting of the function of shadow-puppet as part of ritual ceremonies into performing arts, shadow-puppet performances today are often accompanied by gamelan in pelog scale. When there is a transition, either from slendro to pelog or between patets with one another, there is a melody that allows a pleasant transition to be felt both by the pengrawit (music players) and the listener. This article explores various transitional melodies found in shadowpuppet shows. The transitional melodies are known ats thinthingan and grambyangan. Thinthingan and grambyangan are played by the gender, an ensemble of methalophone gamelan instruments. and in some cases thinthingan is sounded by the dalang's vocal mim-
icry of the gender.

\section{THE SOUND SPACE IN THE SHADOW-PUPPET SHOW}

Prasetya's research (2012) ascertained that patet was a sound space. A person who plays gamelan can be analogous to being in a sound space. In general, there are three sound spaces, 
namely patet nim room, patet sanga room and patet manywa room. One who originally plays gamelan in the patet nem room could not suddenly play gamelan in the patet sanga or mamyra room. In order to be able to play on different patets, one must open the door first (Prasetya, 2012). Three patet doors, starting from the simplest one are thinthingan, senggrengan and grambyangan. Prasetya's research did not explain why thinthingan, senggrengan and grambyangan were able to open the door of the patet room.

Shadow-puppet shows, both in the form of overnight shows (five to seven hours), concise (two to four hours) or solid (less than one hour) can be seen as sound spaces. Based on observations during shadow-puppet shows, the music is continuous. Gamelan music continues to be played with different intensities to complement each other and strengthen the feeling of shadow-puppet shows. When puppet characters deliver a dialogue or when a puppet master or dalang gives a narrative, the music sounds with a low intensity. Only one or several music instruments are played. Conversely, when puppets are moved, arranged on the kelir (screen), walking. dancing or making war, the music sounds with high intensity. Nearly all of the music instruments are played (see Table 2).

Table 2 shows that during the performance music always accompanies the actions. To understand this, I observed one of the overnight wayang performance plays called Kakrasana Wanengpinta, which was performed by Ki Cerma Suteja, one of the dalangs from Yogyakarta.

Table 2. Relationship among performance aspects with the music is played

\begin{tabular}{lll}
\hline No Performance aspect & Music played & Instrument \\
\hline 1. Puppets are in dialogue & Grimingan & gender \\
2. Puppets are moving (walk, fight) & Gending (gamelan piece) & all gamelan instruments \\
3. Puppets in a certain mood (sad, & Sulukan (thood song) & $\begin{array}{l}\text { gender, rebab, gambang, seruling, } \\
\text { cempala, keprak, gong }\end{array}$ \\
4. The dalang is giving a narrative & Grimingan & gender, keprak \\
\hline
\end{tabular}

Source: Hanggar and Nuryanta. 2018

Table 3. Sound space in shadow puppet performance.

\begin{tabular}{|c|c|c|}
\hline Patet & Jejer/Scene & 'Gending (Name of Gamelan piece) \\
\hline \multirow[t]{5}{*}{ Nem } & $\begin{array}{l}\text { Jejer I. The begining. Mandura Country. Har- } \\
\text { yaprabu. Patih (Prime minister) Saragupita, } \\
\text { Narayana meets Prabu Basudewa. Basudewa } \\
\text { would crown Kakrasana to replace him as the } \\
\text { king. but Kakrasana leaves the kingdom with- } \\
\text { out saying a word. }\end{array}$ & $\begin{array}{l}\text { Ayak-ayak Slendro Patet Nem, Gending Kat- } \\
\text { awitan Slendro Patet Nem, Ladrang Krawitan } \\
\text { Slendro Patet Nem, Suluk Lagon Patet Nem } \\
\text { Wetah, Suluk Kawin Girisa Patet Nem, Gri- } \\
\text { mingan Patet Nem, Suluk Ada-ada Patet } \\
\text { Nem Wetah, Grimingan Patet Nem, Playon } \\
\text { Patef Nem }\end{array}$ \\
\hline & $\begin{array}{l}\text { Kundur Kedhaton; Prabu Basudewa returns } \\
\text { to the palace }\end{array}$ & $\begin{array}{l}\text { Ladrang Sri Katon Patet Manyura, Ayak-ayak } \\
\text { Lavem Patet Nem }\end{array}$ \\
\hline & $\begin{array}{l}\text { Paseban Jawi: Patih Satagupita and Tumeng- } \\
\text { gung meet Haryaprabu. }\end{array}$ & $\begin{array}{l}\text { Suluk Ada-ada Patet Nem Jugag. Grimingan } \\
\text { Patet Nem. Playon Patet Nem, Grimingan }\end{array}$ \\
\hline & $\begin{array}{l}\text { Budhalan: Haryaprabu and the soldiers join } \\
\text { in a campaign to find Kaktasana. }\end{array}$ & $\begin{array}{l}\text { Patet Nem, Suluk Ada-ada Patet Nem Wetah } \\
\text { Swhk Ada-ada Kawin Sekar Asmaradana } \\
\text { Patet Manma. Suluk Kawin Sekar Pangkur } \\
\text { Pate Sanga. Lancarwn Gagak Setra Patet } \\
\text { Sanga }\end{array}$ \\
\hline & $\begin{array}{l}\text { Jejer II. Sabrangan. Girigathok Country. } \\
\text { Bedongbau and Bramangkara meet Patih } \\
\text { Nagarangsang. They leave for Kayangan }\end{array}$ & $\begin{array}{l}\text { Plavon Lasen Paret Nem. Suluk Ada-ada } \\
\text { Patet Nem Wetah. Grimingan Patet Nem, } \\
\text { Playon Lasen Patet Nem }\end{array}$ \\
\hline
\end{tabular}


Table 3. (Conimued)

\begin{tabular}{ll} 
Patet Jejer/Scene & 'Gending (Name of Gamelan piece) \\
\hline
\end{tabular}

Kandhawaru to propose to Gagarmayang and Parijatha

Midway scene. Patih Nagarangang are accompanied by Togog and Bilung.

War Scene: Patih Saragupita fights against Gedongbau. Gedongbau loses, and then he continues the journey

Jejer III. Jongringsaloka Heaven: Batara Guru order Narada, Brama, Indra and Yamadipati to send Patih Nagarangsang back.

Repat Kepanasan Scene. Brama. Indra. Sambu, and Mahadewa meet Batara Narada Midway scene. Patih Nagarangsang is accompanied by Togog and Bilung.

The scene of Brama meeting Patih Nagakilat. War scene: Brama fights Nagarangsang. Brama loses.

Brama meets Narada and reports his loss.

Brama release a fog so that the Nagarangsang cannol see

Narada tells Indra to look for a champion who can defeat Nagarangsang.

Sanga Gara-gara (consists of humor and messages)

Petruk sings a Patet Sanga song.

Senar sings songs of Pated Sanga and Patet Manyura.

Jejer IV. Pandita: Ringin Gedabya. Margana. Semar, Gareng. Petruk, and Bagong meet Begawan Wanengunta. They are visited by Indra. Indra asks for help to expel Patih Nagarangsang.

War scene. Margana fights against Cakil.

War scene. Margarana fights against Patih Nagarangsang. Patih Nagarangsang is thrown away.

Jejer V. Surateleng Heaven. Pertiwi and Setija meet Nagaraja. Setja wants to meet his father Narayana. Nagaraja summons Narayana and hands him the Wijayakusuma Flower to revive the person who died prematurely.

Manyura Jejer VI. Girigathok country. Prabu Nagakilat will follow Patih Nagarangsang who had not gone home.

Kandhawaru scene: Nagakilat meets Nagarangsang.
Playon Lasem Patet Nem, Grimingan Patet vem

Playon Lasem Patet Nem. Suhk Ada ada

Patet Nem, Grimingan Patet Nem

Ladrang . Mega Mendhung Pelog Patet Nem, Suluk Plencung Jugag Pelog Patet Nem, Adaada Pelog Patel Nem wetah, Grimingan Pelog Patet Nem

Playon Lasem Pelog Patet Nem, Grimingan Pelog Patet Nem

Playon Lasem Pelog Patet Nem. Suluk Adaada Pelog Patet Nom, Griningan Pelog Pater $N$ m

Suluk Ada-ada Slendro Patet Nem

Plityon Lasem Patet Nem, Grimingan Patet $\mathrm{Nem}$

Playon Lasem Patet Nem, Grimingan Patet Nem

Playon Lasen Patet Nem, Grimingan Patet Nem

Ployon Lasem Patet Nem

Sunk Lagon Paret Sanga Wetah, Ilir-ilir song with Patet Sanga, Suluk Ada-ada Gara-gara, Ayak ayak Patet Sanga, Playon Patet Sanga,

Sampak Patet Sanga, Playon Patet Sanga

Lagu Slendhang Biru Patet Sanga, Playon

Patet Sanga. Sampak Pater Sanga

Suluk Jingking Wetah Patet Sanga, Jineman

Patet Sangit. Grimingan Pater Sanga

Suluk Sekar Pucung Pakt Manvura

Ladrang Sri Kaloka Patet Sanga, Suluk

Lagon Patet Sanga Wetah, Grimingan Patet

Sanga, Suluk Ada-ada Patet Sanga

Suluk Ada-ada Patet Sanga, Grimingan Patet Sanga, Playon Patet Sanga.

Playon Patet Sanga, Grimingan Patet Sanga

Playon Patet Sanga, Suluk Lagon Pater Sanga Wetah. Grimingan Patet Sanga. Playon Patet Sanga, Suluk Lagon Patet Sanga jugag. Grimingan Patet Sanga, Playon Patet Sanga

Suht: Lagon Patet Manyara Wanah, Griningan Patet Manyura. Suluk Ada-ada Pelog Barang

Platyon Pelog Barang. Grimingan Pelog Barang 


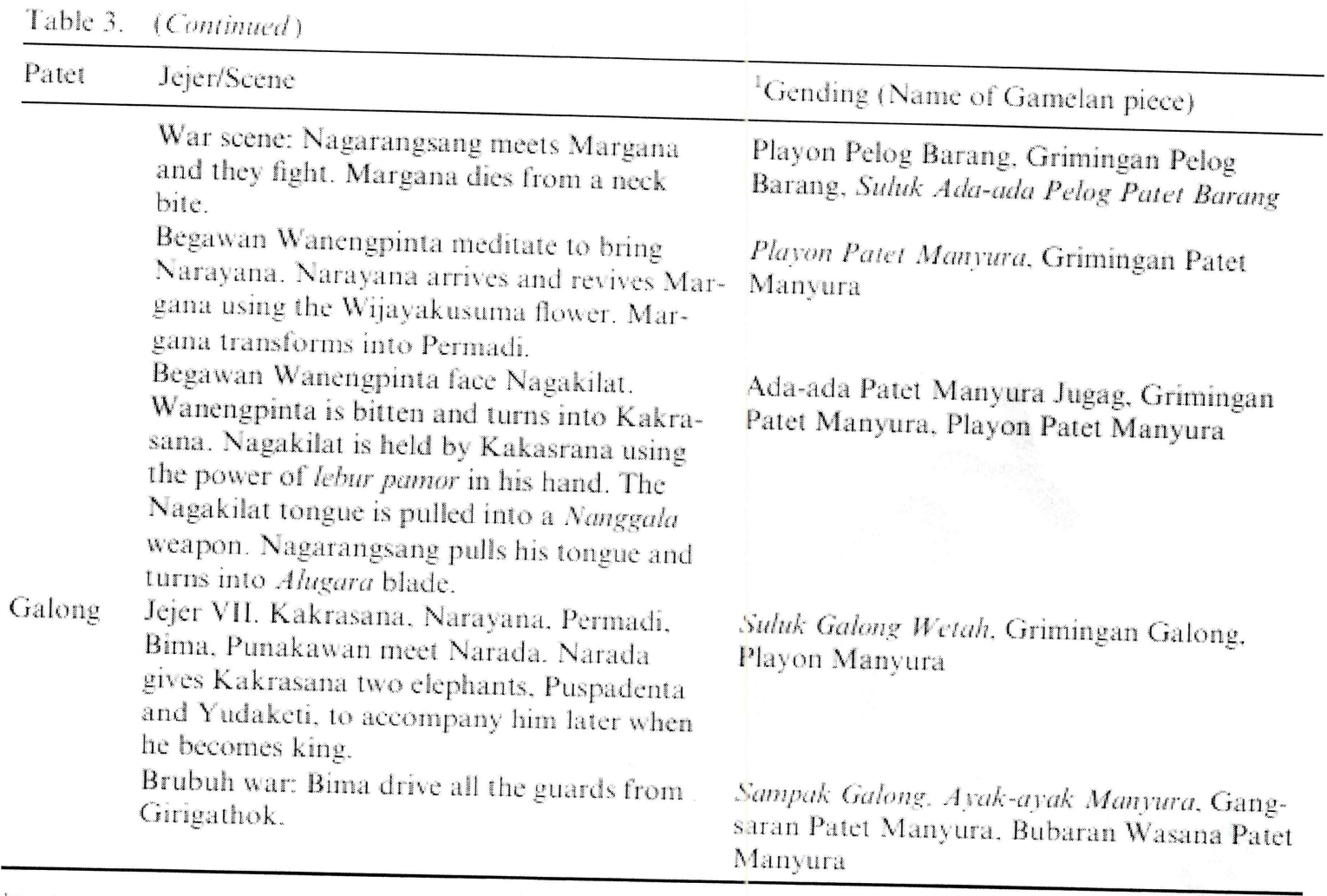

\footnotetext{
'Italic letters to indicate a patet transition.
}

This show tells the story about the two sons of the king of Mandura. Narayana and Kakrasana, who receive a gift from a god so that later it would be revealed who is worthy to become a king. Narayana managed to get the Wijaya Kusuma flower to revive the dead whose time had not come yet, while Kakrasana obtained Nanggala and Alugara weapons and two elephants, Gajah Puspadenta and Yudakethi. This show lasts for 6 hours.

\section{TRANSITIONAL MELODY OF MUSIC FOR WAYANG} To facilitate the discussion, the following transitional melodies are included in each patet
section.

\subsection{Patet Nen}

In the Patet Nem segment, the patet changes oceur six times, namely when the show has started, the Kundur Kedhaton scene, the Paseban Jawi scene, Jejer II, Jejer III and the scene of Brama meeting with Patih Nagarangsang.

\subsubsection{The Beginning of the show}

When the puppet will begin, a transition takes place between patet sanga and patet nem. In the transition from patet sanga to patet nem, there is a transition melody in the form of grambyangan of patet nem. Before the puppet show begins, gamelan music has been sounded by playing patalon pieces. Patalon pieces consists of compositions or pieces with patet sanga, namely: Gambir Sawit, Ladrang Pangkur, Ketawang Langen Gita, Ayak-Ayak Sanga, Playon Sanga, and Sampak Sanga. The melody of grambyangam Patet Vem is as follows

After the grambyangam, the dalang gives the cues or comand in the form of dhodhogan (tapping the wooden puppet box with a cempala or a mallet) live times, followed by Ayak-ayak
Patet Nem. 


$$
\begin{aligned}
& 652.3 \\
& \overline{\ldots .6 .} \\
& 53 \ldots \quad 21 \ldots \quad \ldots 3 \quad \ldots . \quad \ldots \\
& \overline{.53} \quad \overline{.21} \quad \overline{.23} \quad \overline{.123} \quad \overline{.332} \\
& \begin{array}{llll}
.653 & \ldots 2 & \ldots 5 & \ldots 6 \\
\ldots . & \frac{.532}{.35} & -\frac{.356}{.56}
\end{array} \\
& \frac{\ldots 5}{53565} \quad \frac{.3 .3}{.356} \quad \ldots 2 \\
& .6 i 2 \quad i 6 i 6 \\
& \overline{\cdots+2}
\end{aligned}
$$
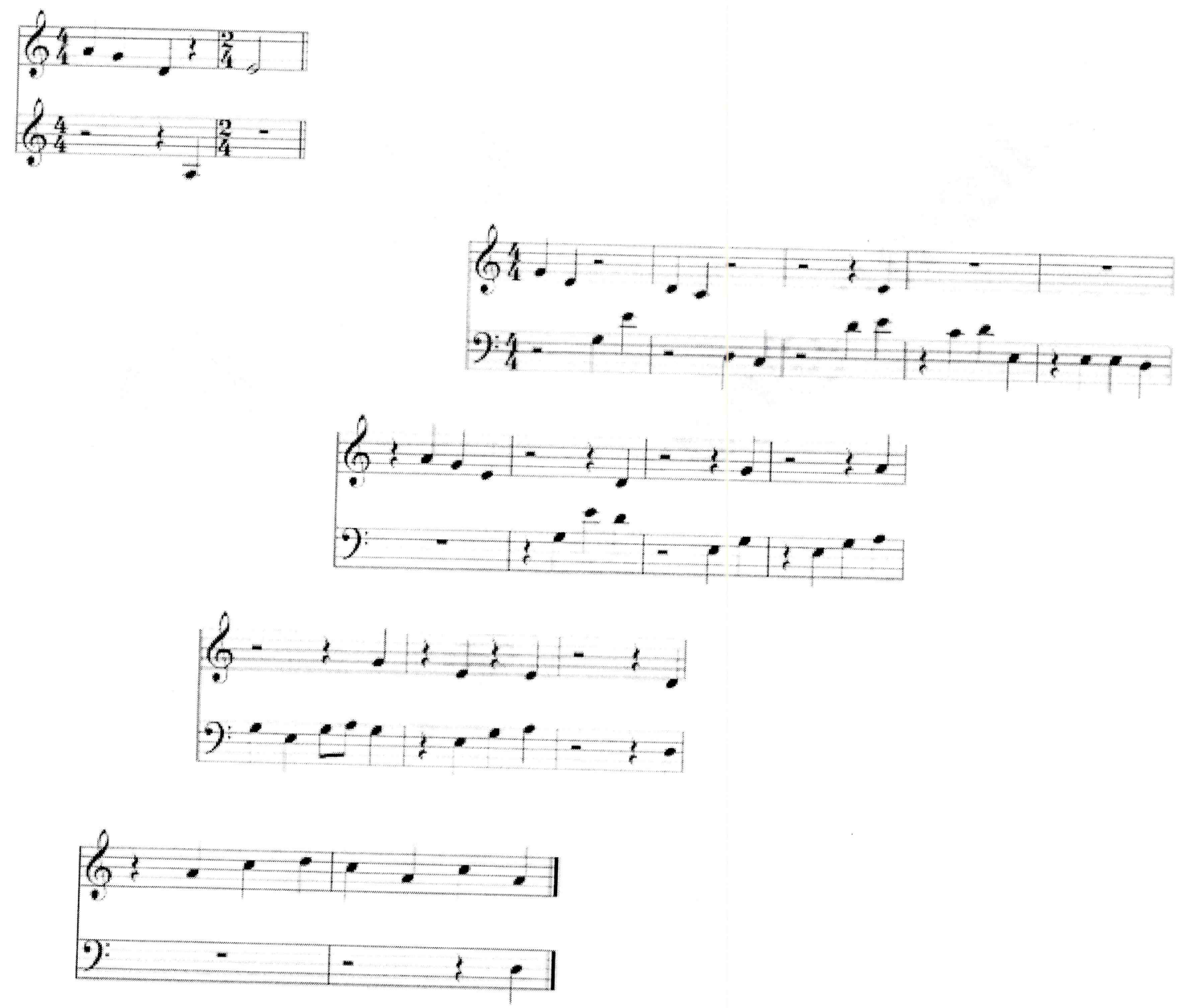

Figure 1. Grambyangan patet nem. 


\subsubsection{The scene of Kundur Kedhaton}

This scene is accompanied by Sri Katon Patet Manyura Ladrang compositions. Thus, in this section there is a transition from patet nem to patet manyura. The transition melody used is in the form of Manyura grambyangan as follows.

$$
\begin{aligned}
& 3216 \quad 53 \ldots .61 . \\
& \bar{\ldots} \quad-\quad \cdots \\
& \cdots, \quad \ldots \quad .321 \\
& \overline{561} \quad \overline{.111} \quad-\ldots 1 \\
& .232 \quad \begin{array}{lllll}
.216 & \ldots 53 & \ldots 21 & \ldots
\end{array}
\end{aligned}
$$

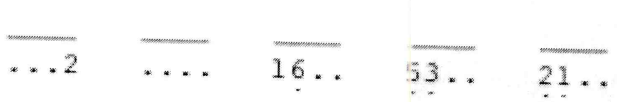

$$
\begin{aligned}
& \begin{array}{llll}
.23 & \ldots & \ldots & .161
\end{array} \\
& \bar{\cdots} \quad \overline{.123} \quad \overline{.333} \quad \overline{\ldots 3}
\end{aligned}
$$
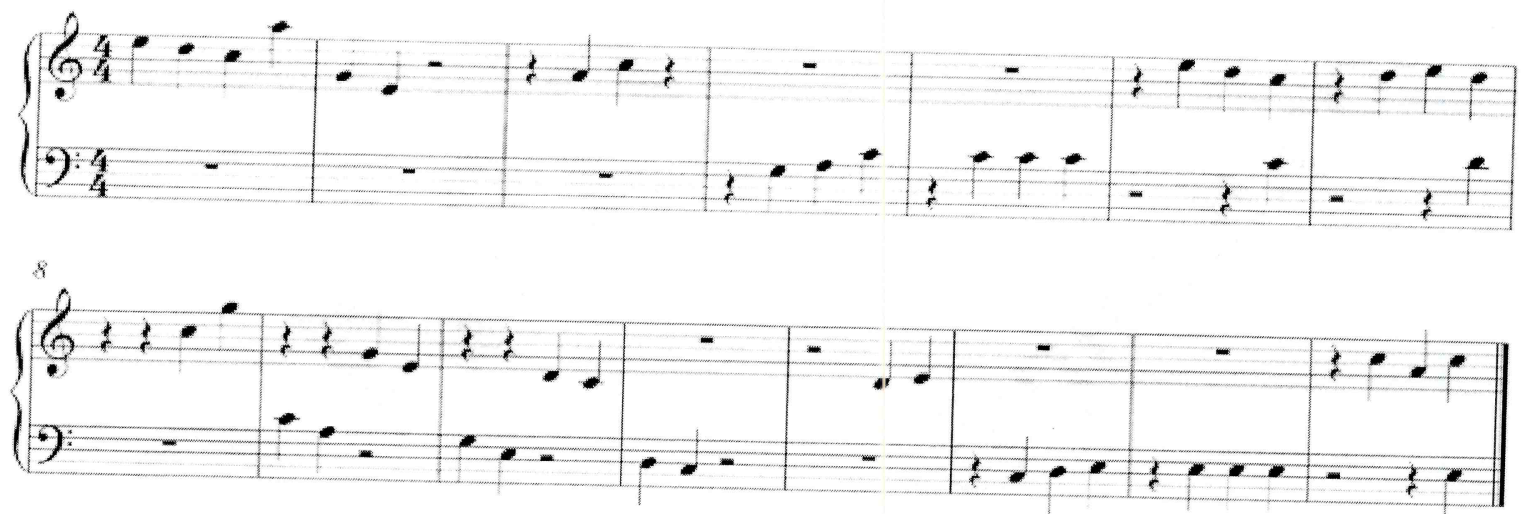

Figure 2. Grambyangan of manyura.

The above melody is played by gender players after the dalang gives a code or sasmita with the phrase "Katon Tejane" as a sign so that the gamelan players play the Ladrang Srikaton piece. After playing the Ladrang Srikaton Patet Manyura piece. the gamelan players continue the Ayak-ayak Lasem Patet Nem. Srepeg Lasem Pate Nem, and Playon Lasem Patet Nem pieces without the transition melody of thinhingan or grambyangan. The transition melody used is Ayak-ayak with the tone of 2356. Although patet changes occur, this part is not a problem because the taste between Patet Nem and Manyura is very close.

Ladrang Srikaton Pater Manyura
$\begin{array}{ccccc}\text { Opening: } & 3.32 & 3.32 & 3.32 & 3.32 \\ 15653 & 2121 & 3565 & 3212 & \\ 5653 & 2121 & 3565 & 3212 \\ 66.5 & 3561 & 3265 & 3235 \\ 3353 & 5616 & 3565 & 32121\end{array}$



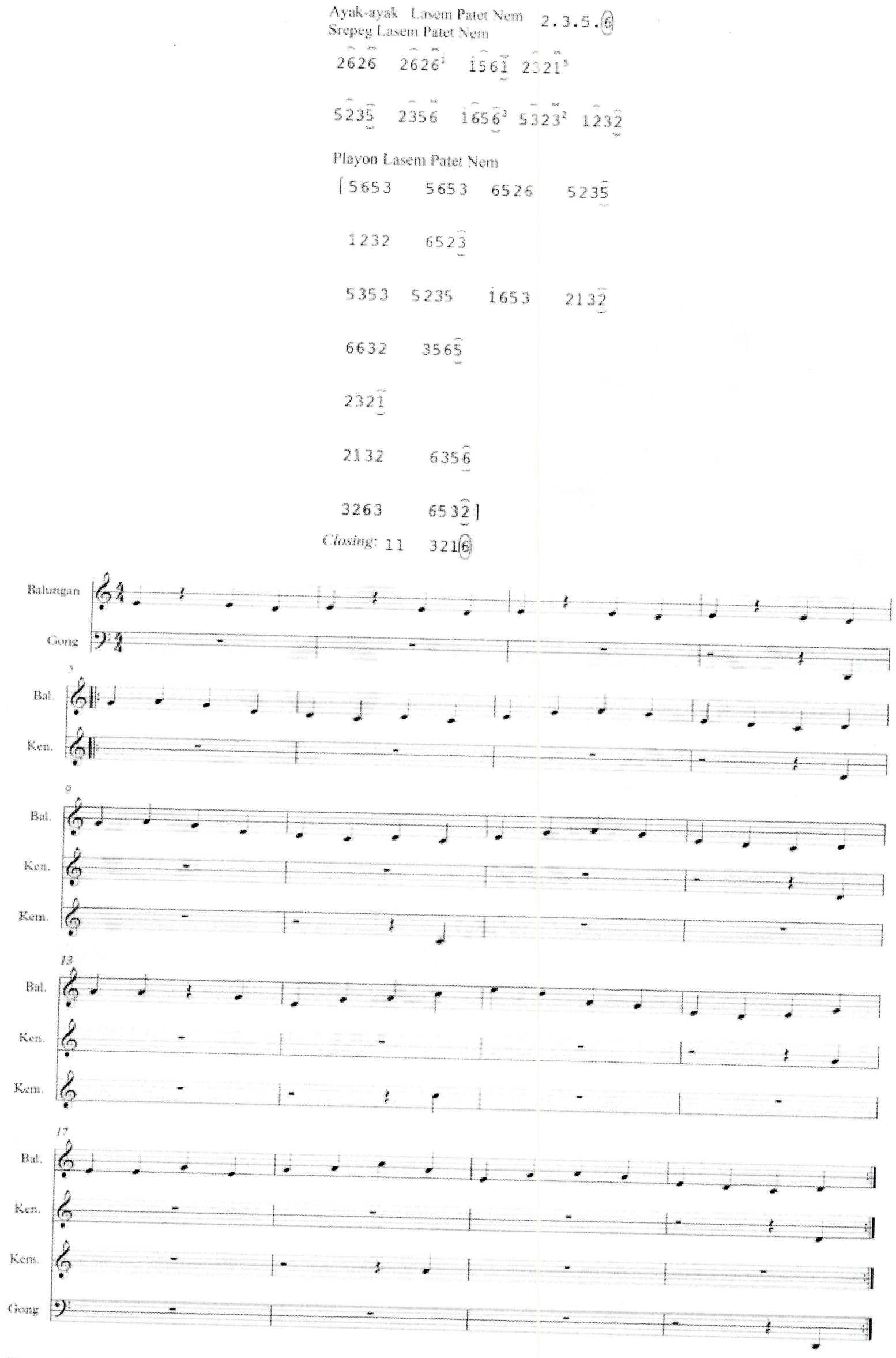

Figure 3. Ladrang sri katon patet manyura. 
Ayakwayak Lasem Patet Nem
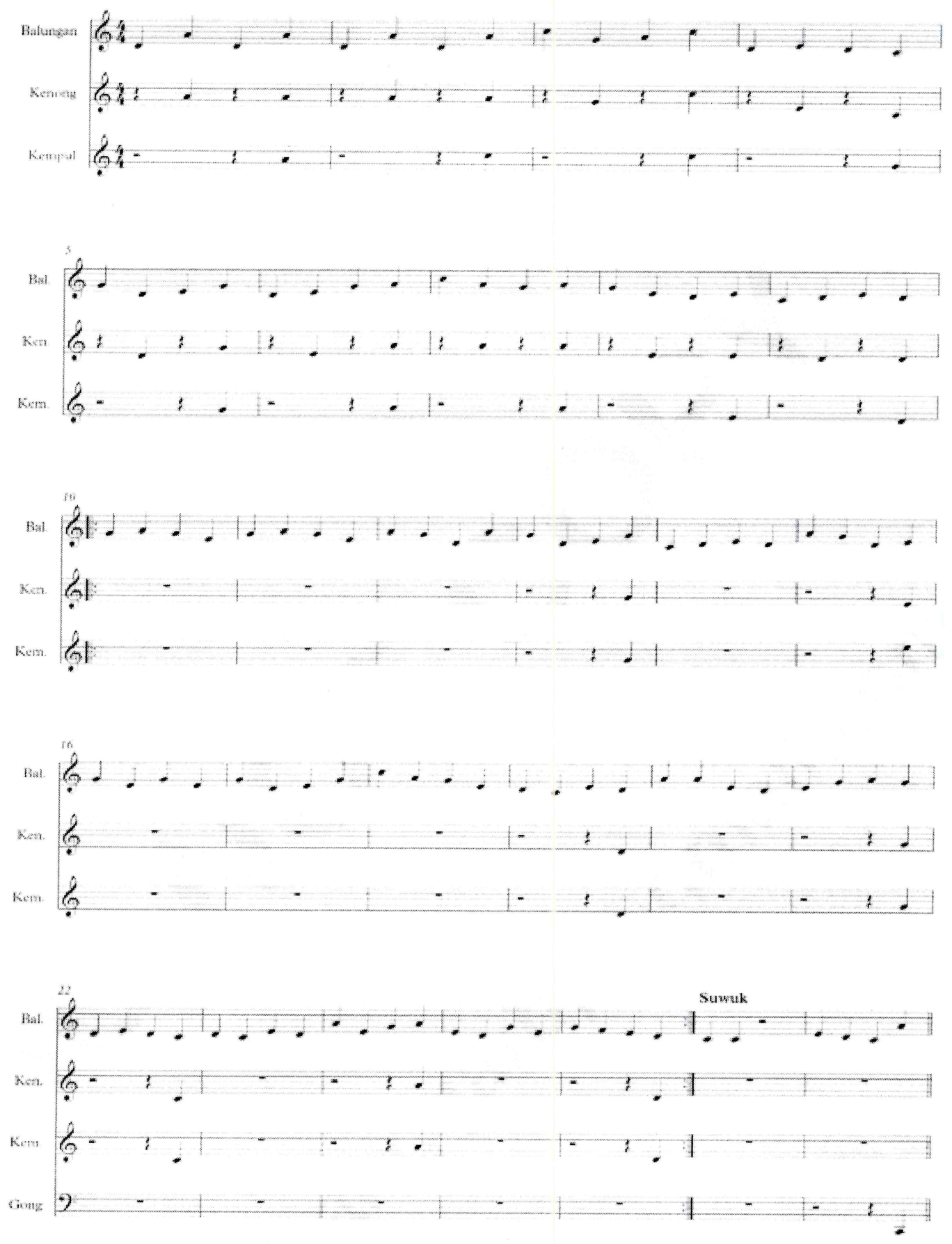

Figure 4. Ayak-ayak lasem patet nem and srepeg lasem patet nem.

In the last row of the Ladrang Srikaton piece following the 3565 tone, the tone does not go to 3212 but to 2356 with a slowing tempo. Although the gong tone is different in which the gong of $2(3212)$ is replaced by the gong of $6(2356)$, it does not create any problem because tone 6 is the kempyung of tone 2. Musically, the kempyung tone is close.

\subsubsection{The seene of paseban jawi}

In this section, there was a change in the patet from patet nem to patet manyura, then patet samga. Originally, the gamelan music pieces played are Playon Lasem Patet Nem - Suluk Adaada Kawin Sekar Asmaradana Patet Manyura - Song of Suluk Ada-ada Sekar Pangkur - 
Lancaran Gagaksetra Patet Sanga. Therefore, the transition is as follows: Playon Lasem thinthingan Manyura (gender) - Suluk Ada-ada Sekar Asmaradana - thinthingan Sanga (vocal dalang) - Lancaran Gagaksetra. The transition from patet manyura to patet sanga is done by the dalang vocally imitating thinthingan with the sounds of the bende. drum and terimpet when there will be a departure of soldiers within songs as in the following:

Mungmung jir Tret tret trit tret tret tret tret ret tril tret drang drang dum

$\begin{array}{llllllllllllllll}6 & 6 & 2 & 6 & 6 & 2 & 6 & 3 & 5 & 3 & 5 & 6 & 2 & 6 & 6 & 2\end{array}$

\footnotetext{
Mung mung jir Trettret trit tret fret tret tret tret trit tret drang drang dur...mung mung jir

$\begin{array}{llllllllllllllllllllllll}6 & 6 & 2 & 6 & 6 & 2 & 6 & 3 & 5 & 3 & 5 & 6 & 2 & 6 & 6 & 2 & 5 & 5 & 1\end{array}$
}
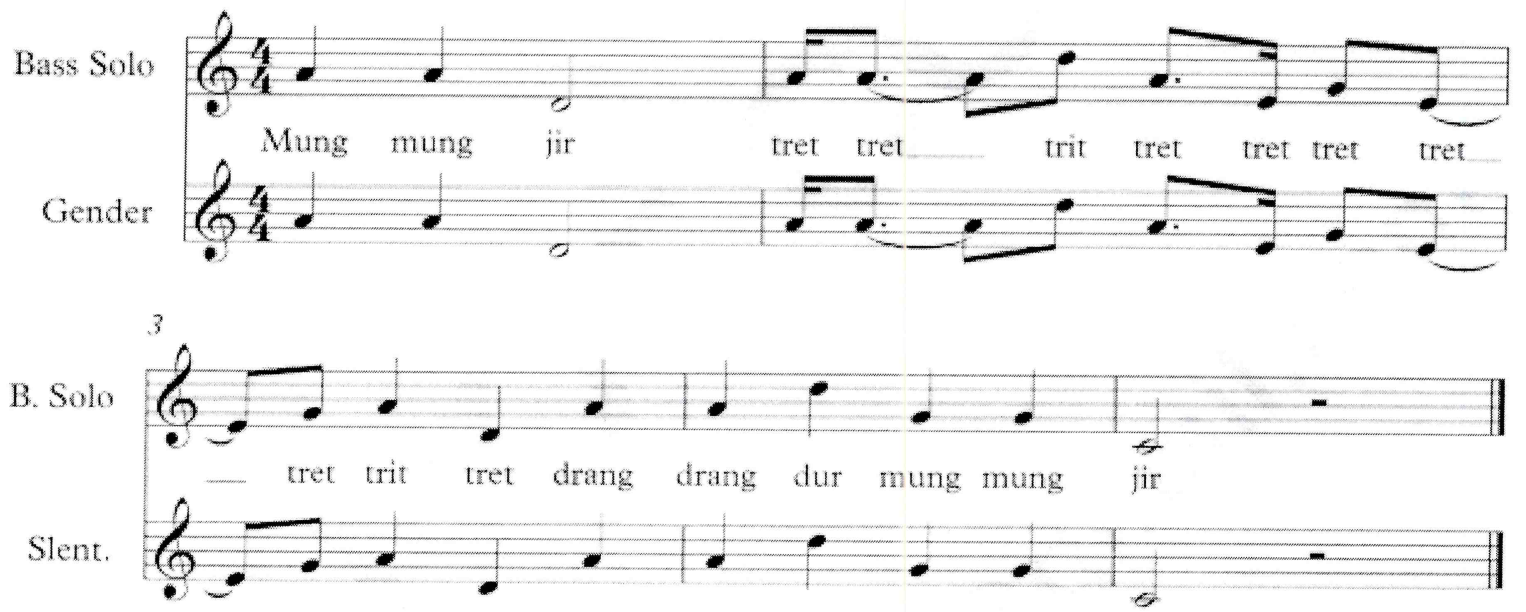

Figure 5. Vocal dalang as thinhingan.

The song is actually thinhingan as the transition from patet manyura to patet sanga. The initial sounds are tones 6 and 2 which are the patet manyura tone areas, while the final tones 5 and 1 are the patet sanga tone areas. After the thinthingan was continued by a vocal song of the dalang singing Kawin Sekar Pangkur Patet Sanga, it was continued by the Lancaran Gagak Setra Patet Sanga piece. This music is used to accompany the departure of soldiers.

\section{1 .4 Jejer $/ 1$}

This section uses the Playon Lasem Patet Nem piece, although in the previous case, the music was Lancaran Gagak Setra Patet Sanga. So here a transition occurs and the transition melody used is the grambyangan patet nem.

\section{1 .5 Jejer $/ 1 /$}

This section is accompanied by the Ladrang Mega Mendung Pelog Patet Nem piece. The previous scene used the Playon Lasem Slendro Patet Nem piece. Here there is at change in the type of gamelan used, namely from the slendro gamelan scale to the pelog scale. The transition used is the grambyangan Pelog Patet Nem melody as in the following: 


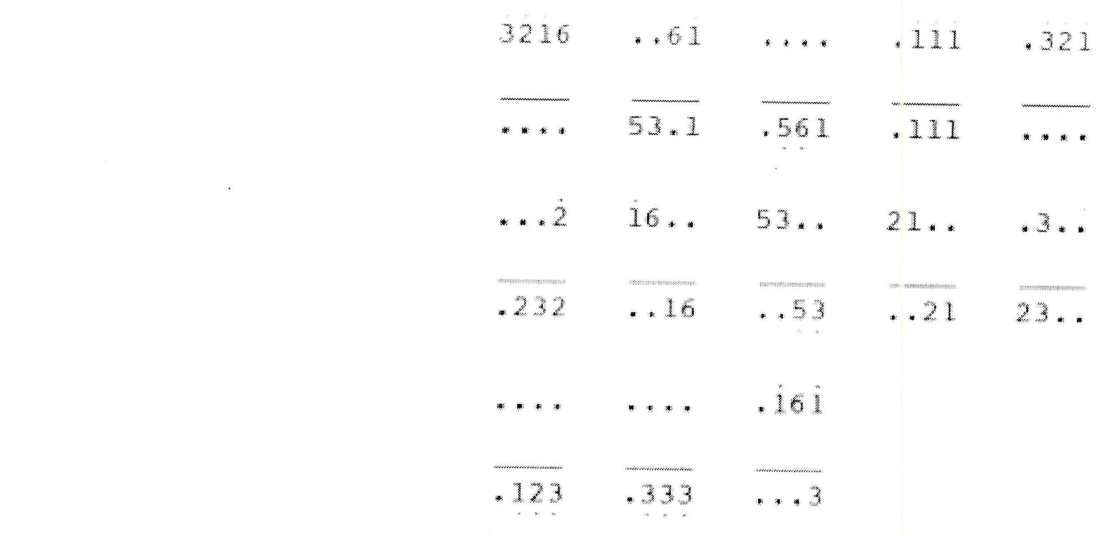

\section{Grambyangan Pelog Patet Nem}
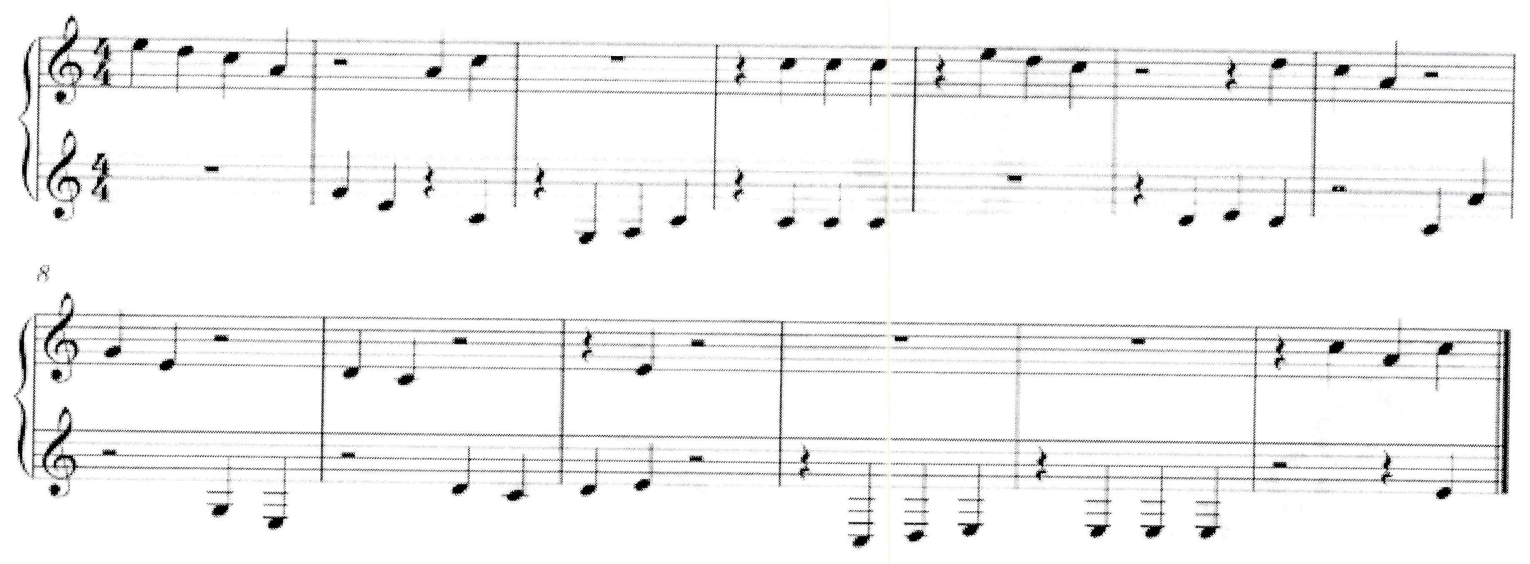

Figure 6. Grambyangan pelog patet nem.

After completing the grambyangan, it is followed by gamelan pieces and vocal songs in the pelog scale until it ends with the scene of Brama meeting Patih Nagarangsang.

3.1.6 The scene of Brama meating Path Nagurangsang

In this section there is a change in scale, from pelog patet nem to slendro patet nem. To begin this scene there is grambrangan patet nem. This was done becase previously it was gamelan pieces and vocal songs on pelog scale. The gamelan pieces with patet nem continue until the scene of Gara-gara which is played on patet sanga.

\subsection{Patet sunga}

In the patet sanga segments, there are four patet changes: in the scenes of Gara-gara, Petruk singing, Semar singing and jejer IV.

\subsubsection{The Scene of Gara-Gara}

The scene of Gara-gara applies the earliest patet sunga. Thus, a process of change from patet nem becomes patet sanga that occurs in this scene. The patet transition uses patet sanga's grambyangan as follows.

$$
\begin{array}{llll}
2165 & .3 .2 & .3 .5 & \\
\ldots \ldots & \ldots . & \ldots & \\
\ldots & \ldots & .165 & .212 \\
\frac{.222}{.555} & \ldots \ldots & \ldots 5
\end{array}
$$




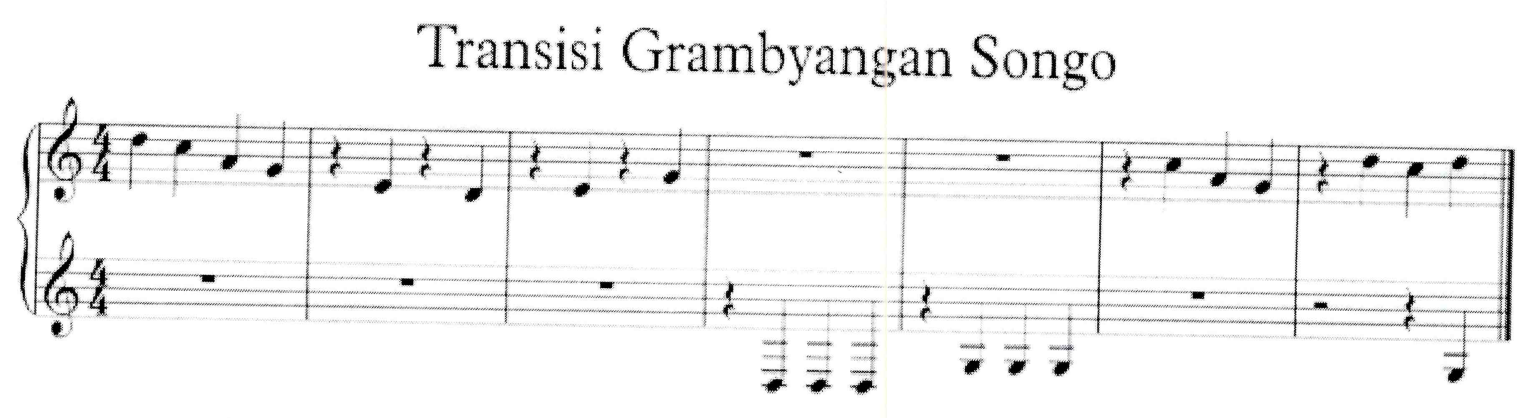

Figure 7. Grambyangan sangat.

After the granbyangan, the atmosphere brings a feeling of patet sanga. This taste is strengthened by the mood song of Suluk Lagon Patet Sanga.

\subsubsection{The scene of Petruk Singing}

The character of Petruk sings in pater sumga because Petruk is supposed to be sung in the atmosphere of the patet sanga segment. Since there is dialogue and grimingan (gender sounds accompanying the dalang as he speaks) beforehand. during this performance the dalang did not hear well enough. Because the dalang lost the atmosphere of the patet, through the character of Petruk the dalang sang ma ma ma $j i j i$ vocals followed by gender voices of the 5 and 1 tone. After this, the dalang then sings the song of Slendang Biru Slendro Patet Sanga with the
initial tone of 5 .

\section{2 .3 The scene of senat}

In this section, there is a transition from patet sanga to patet manyura. The previous music was Sampak Patet Sanga. When Semar arrived, the gamelan piece stopped (suwuk). When Semar sings, the gamelan musicians make thinthingan by ringing ning ning ning nong nong nong followed by gender tones 666222 . This thinthingan is able to turn patet sanga into patet manywa. After this thinthingan, Semar sings Suluk Sekar Pucung Patet Manyura.

\section{2 .4 Jejer $I V$}

This section uses the music of the Ladrang Sri Kaloka Patet Sanga piece. Previously, it was a piece with patet manyma. Thus, there is a change in patet here. The transition melody used was grambyangan patet manyara. The Ladrang Sri Kaloka piece is followed by vocals and playing the patet sanga piece and lasts until jejer VI.

\subsection{Patet manymat}

Patet manywa starts on jejer VI. In the patet manyura section there are two transitions, in jejer VI and in the scene of the Wanengpinta meditating to bring Narayana.

\subsubsection{Jejer $\mathrm{VI}$}

Jejer VI begins with grambyangan manywa to change the atmosphere from patet sanga to patet manyara. After the grambyangan continues, the dalang vocalises a mood song in the form of Suluk Lagon Patet Manyura Wetah. However, the atmosphere of patet manyara only lasts for a short time only to open the patet. After that, there is grambyangan pelog to prepare the piece with pelog scale. After singing the Suluk Lagon mood song, the dalang narrates the next scene. When the dalang narrates the scene, the gender musicians begin to play grambyangan pelog barang to change the atmosphere 10 polog. The following is the grambyangan pelog harang. 


$$
\begin{array}{llll}
2765 & \ldots 35 & \ldots & \ldots \\
\ldots \ldots & 32 \ldots & \frac{.235}{.555} \\
.765 & \ldots 6 & \ldots 5 & \\
\ldots & \frac{.356}{53565} & \\
.3 .3 & \ldots 2 & .672 & 7676 \\
\frac{.356}{32} & \ldots & \ldots & \ldots 2
\end{array}
$$

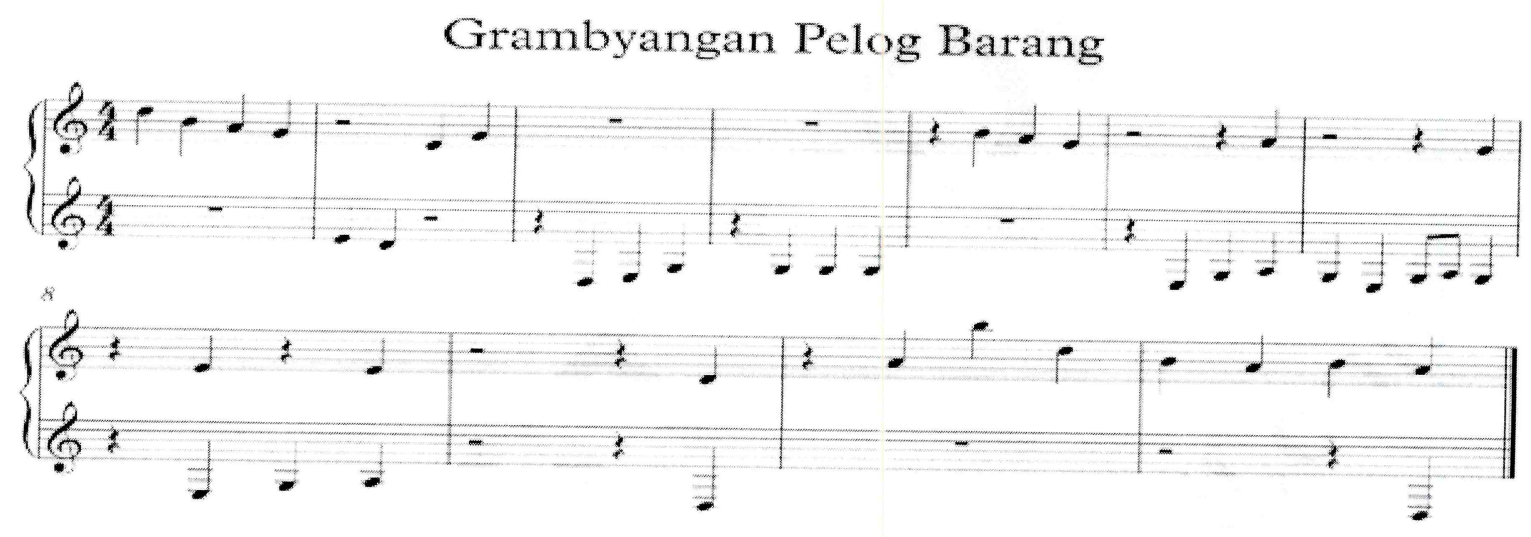

Figure 8 . Grambyangan pelog barang.

After grambyangan pelog barang, all the mood songs and gamelan pieces play at pelog barang, the pelog barang atmosphere lasted until the scene of Begawan Wanengpinta
meditating.

\subsubsection{The scene of begawan wanengpinta meditating}

In this scene, there was a transition from pelog barang to slendro manyura. This transition was in the form of grambyangan mamura. During the fieldwork this atmosphere lasted until the show was finished.

\section{PATET AS A FORM OF MUSICAL TASTE}

Patet is a kind of music mode, but it has different modes. Every patet has a different musical taste. This musical taste is influenced by the intervals of each patet tone. Patet nem has a pitch of 6-5-3-2, patet sanga has intervals of $2-\mathrm{i}-6-5$, while patet manlura has intervals of $3-2-1-6$. At a glance, patet manyura is a note above patet sanga, and patet sanga is a two tones above patet nem. However, it is not as simple as this because the intervals between the tones in the gamelan are not the same. For example, the gamelan at the Puppetry Department of Indonesia Institute of the Arts, Yogyakarta has the following intervals: 


\begin{tabular}{|c|c|c|c|c|c|c|c|c|c|c|c|c|c|}
\hline \multirow[b]{2}{*}{ Note } & \multicolumn{13}{|c|}{ Interval among note $n$ with note nil (cent) } \\
\hline & $5-1$ & $1 \cdot 2$ & $2-3$ & $3-5$ & 5-6. & $6-1$ & 1.2 & $2 \cdot 3$ & 3.5 & 5.6 & $6-1$ & $i-\dot{2}$ & $2 \cdot 3$ \\
\hline Interval & 260 & 237 & 254 & 250 & 229 & 250 & 243 & 238 & 243 & 223 & 263 & 236 & 248 \\
\hline Patet Nem & & & Exis & $y=$ & & & & & & & & & \\
\hline $\begin{array}{l}\text { Patet } \\
\text { Sanga }\end{array}$ & & & & & $\begin{array}{l}\text { Patet } \\
\text { Sang }\end{array}$ & & & & & $\begin{array}{l}\text { Patet } \\
\text { Sangs }\end{array}$ & & & \\
\hline $\begin{array}{l}\text { Putet } \\
\text { Maryura }\end{array}$ & & & & & & $\begin{array}{l}\text { Patet } \\
\text { Many }\end{array}$ & & & & & $\begin{array}{l}\text { Patet } \\
\text { Man }\end{array}$ & & \\
\hline
\end{tabular}

The intervals between the tones in the gamelan will form a different sense of feeling in each patet. If the interval is categorised into three, near, medium and far, then it can be categorised as follows:

$$
\begin{aligned}
& 223-236=\text { near } \\
& 236-249=\text { medium } \\
& 249-262=\text { far }
\end{aligned}
$$

\begin{tabular}{|c|c|c|}
\hline Tone Area & & Impression \\
\hline Patet Nem & 6532 & $223-243-238$ near medium medium \\
\hline Patet Sanga & $2 j 63$ & $236 \quad 26.223$ near lat neat \\
\hline Manyurat & $32 i 6$ & $248 \quad 236-263$ medium neat - far \\
\hline
\end{tabular}

Table 5. Tones in patet.

The feeling of pater is characterised by a leap in tons. This also applies to the repository of patet nem. For example, the piece that is always used in shadow-puppet shows in the patet nem section is the Playon Lasem Patet Nem as follows.

)

Opening: kendang:

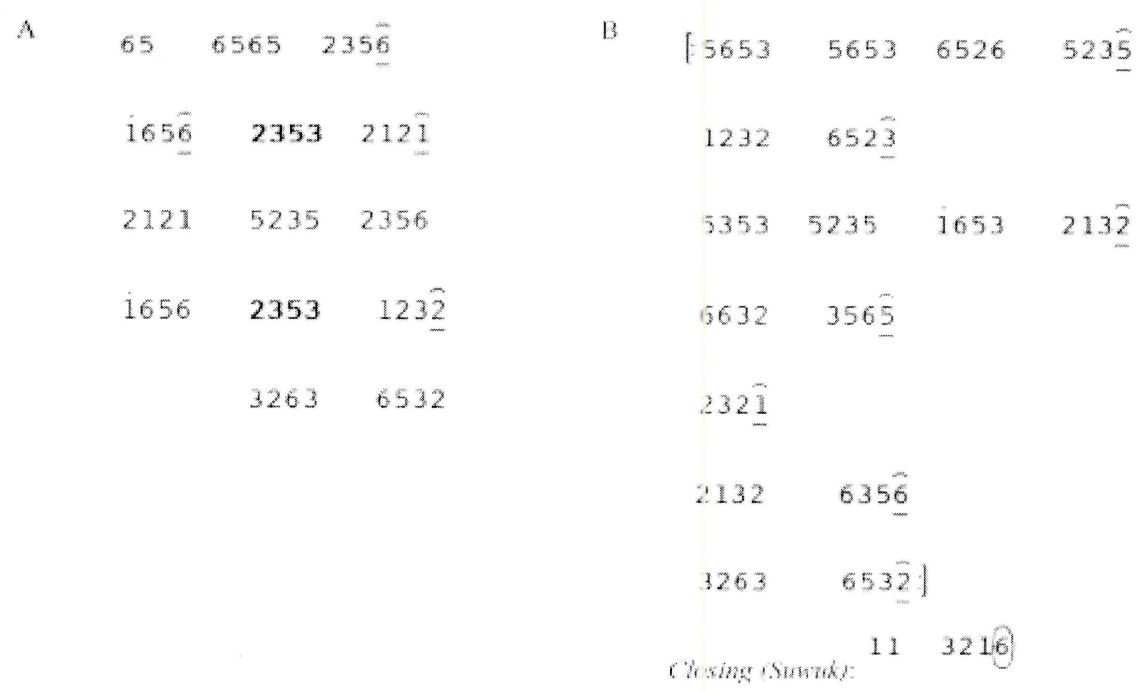




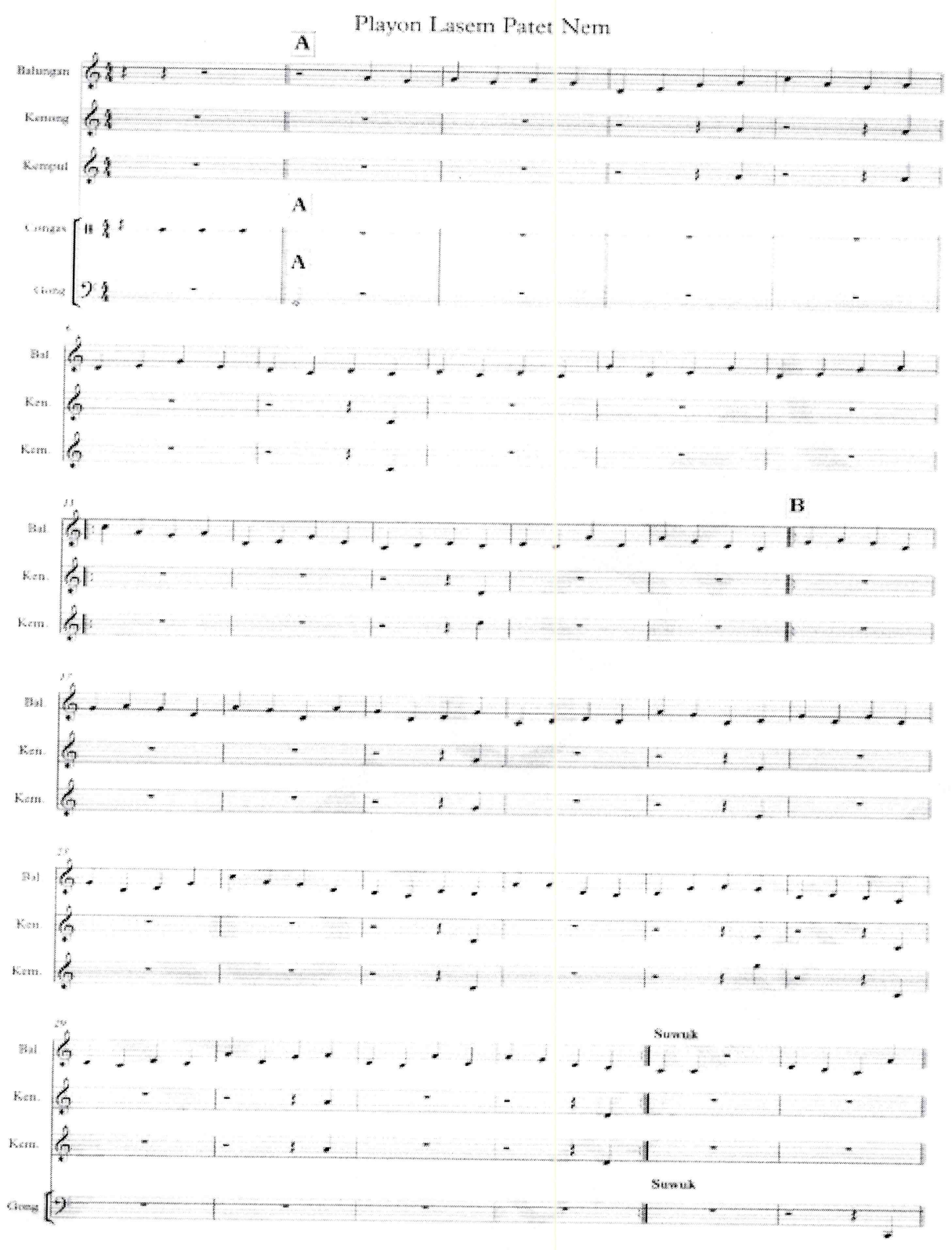

Figure 9. Playon lasen patet nem piece.

\section{CONCLUSIONS}

There are two transitional melodies when there are changes of patets in shadow-puppet shows. namely thinthingan and grambyangan. Thinthingan is usually played if there is a melody that has prepared the transition. Grambyangan melodies are used when there is a strong transition that was not preceded by a strong musical sense, for example, a change in the scale from slendro to pelog or vice versa. Likewise. this happens when there is a transition between patets but with a strong distance, for example, the transition from patet sanga to manyura or vice versa. The transition from patet nem to patet manyura or vice versa, can be played with thinthingan because the taste of melody between patet nem and manyura is not too wide.

\section{REFERENCES}

Brimer, Benjamin. (2008). Music in Central Java. New York: Oxford University Press. 
Lysloft, Rene TA. (1993). A Wrinkle in Time: The Shatow Puppet Theatre of Banyumas. Asian Theatre Joumal. $101 /, 49-80$.

Prasetya, Hanggar Budi. (2012). Pahet: Ruang Buny dalan Karawion Gaya Yogyakarta. Pathet: Spaceof Sound in Yogyakarta's Style Karawitan]. Panggung Jumal Seni dan Budaya. 22 (1), 67-82.

Prasetya, Hanggar Budi. (2013). Mlesed dan Nggandhul dalam Karawitan Pedalangan Gaya Yogyakarta. Diserfawion. [Mlesed and Nggandhul in Yogyakarta's Style of Pedalangan's Karawitan]. Universitas Gadjah Mada Yogyakarta.

Prasetya. Hanggar Budi. (2013). Fisika Bumi Gamelan. [Sound of Gamelan in Physics]. Yogyakarta: BP ISI.

Sutton. Anderson. (1991). Traditons of Gamelan Music in Jara: Musial Pharalism and Regional Jdentity. New York: Cambridge Unversity Press.

Weiss, Sarah. (2006). Lisening to an Earlier Java. The Netherlands: KITLV. 